\title{
Sustaining Open Collaboration in Universities
}

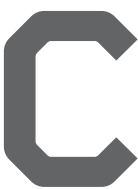

ORE UNIVERSITY MISSIONS Of scholarly education, the advancement of knowledge, and the rigorous evaluation of ideas make universities bastions of open collaboration. In computing, such open sharing has fueled computing's rapid advance and created win-win-win global partnerships in education, innovation, and use, benefitting all. But increasing international tension and distrust, ${ }^{\mathrm{a}}$ and its projection into universities, is eroding open collaboration and inquiry. ${ }^{\mathrm{b}}$

Trade secret and intellectual property walls. In 1980, the Bayh-Dole Act recast universities as intellectual property owners raising new barriers to information sharing in universities. ${ }^{c}$ Technology and trade secrets under non-disclosure agreement (NDA). Exclusive licensing. Competing with industry partners. Billion-dollar litigation. These practices force faculty, staff, and students to self-censor communication: "Have you signed an NDA?" "Have they licensed technology $\mathrm{X}$ ? "Is person $\mathrm{Y}$ consulting at startup Z?" By 2000, an inspired response sought to create "demilitarized zones" for intellectual property. ${ }^{\mathrm{d}}$ As Intel VP of Research, I was stunned by a young professor's decrial of the situation: "Why do I have to understand intellectual property contracts, NDAs, and keep secrets? I became an academic to

a Chien, A. Open collaboration in an age of distrust. Commun. ACM (Jan. 2019).

b I focus on U.S. universities, but those in many countries share these ideals.

c National Research Council. Managing University Intellectual Property in the Public Interest. The National Academies Press, 2011.

d Tennenhouse, D. Intel's open collaborative model of industry-university research. J. RTM, 2004. create new knowledge and share it, not to become an expert in IP law."

In the past two decades, U.S. universities have experienced significant growth in foreign-national students at both undergraduate and graduate levels (now 65\% in computing Ph.D. programs). Drawn by U.S. leadership in computing, and the opportunities of an open university educational and research environment, their contributions to the U.S. economy are well documented. ${ }^{\mathrm{e}}$ International student exchange has benefitted individuals, economies, and nations.

National boundary walls. We are experiencing growing international tension, arising from competition for economic leadership, regional influence and hegemony, and even military advantage, often between political systems (democracy, autocracy). ${ }^{\mathrm{f}}$ The international diversity of university communities translates national sovereignty over citizens directly into boundaries in the university-departments, research groups, or even classrooms. Broadening definitions of sensitive technology imposed by sovereign governments raises new walls. Increasing restrictions on knowledge/technology sharing and interaction with untrusted individuals and entities raise new walls. Interaction restrictions are particularly corrosive-compliance can require off-putting questions-"What is your citizenship?" "Who is your employer?" "With whom, and under what circumstances, can this knowledge be shared?" Recent faculty guidance at a

e Anderson, S. Immigrants and Billion-Dollar Companies. National Foundation for American Policy, Oct. 2018.

f Hong Kong's violent protests against Chinese rule. Economist (July 27, 2019). leading university allowed "speaking with employees of X, but only if they are U.S. citizens."' A standing government directive requires faculty to vet all new collaborations with a list of untrusted individuals and entities. $^{\text {h }}$

Fewer walls. Shaping less damaging walls. What to do? Walls arise from different forces. We have learned to shape those that arise from the profit motive, shaping them to balance inquiry with entrepreneurship. Walls that arise from national security and sovereignty cannot be resisted; so perhaps, in analogous fashion, we can shape them to minimize damage to open collaboration.

To this end, faculty should engage and shape policies to limit the harm of rising barriers and defend university missions of education, invention, and rigorous evaluation. This spirited defense must be in the cause of societynot perceived as a parochial "academic" or research community interest.

The ACM and IEEE Computer Society, as international leadership organizations, must work to shape national policies around the world to support open collaboration and inquiry in universities.

\section{Andrew A. Chien, E DITOR-IN-CHIE F}

Andrew A. Chien is the William Eckhardt Distinguished Service Professor in the Department of Computer Science at the University of Chicago, Director of the CERES Center for Unstoppable Computing, and a Senior Scientist at Argonne National Laboratory.

Copyright held by author/owner.

g Lee, J.L. Huawei's U.S. research arm builds separate identity. Reuters (June 24, 2019).

h U.S. Department of Treasury's Office of Foreign Asset Control Sanctions Programs; http:// www.treasury.gov/ 